\title{
Editorial
}

\section{Tribute to John Taylor}

It's no wonder that the Taylors have been responsible for the identification and distribution information of more native Oklahoma species than anyone else, worldwide; John loved working in the field more than anything else he did. He and Connie traveled extensively and exhaustively throughout their careers. He was active in the Oklahoma Academy of Science and Oklahoma Native Plant Society and Connie, even in her retirement, continues her active participation in these organizations.

It is an honor to include John's 1967 Master's thesis in this volume of the Oklahoma Native Plant Record, as we continue to bring historic and significant scientific work into the hands of today's botanists and ecologists. We thank Connie for updating the format and condensing some of the information for optimal access by current readers. She helped John collect data and prepared the original manuscript for his thesis. She is still a major source of taxonomic expertise for Oklahoma species and the following testimonials are a tribute to her work as well.

"The book 'An annotated list of the ferns, fern allies, gymnosperms and flowering plants of Oklahoma' has been indispensable to me and my students over the past fifteen years. It has been so helpful to be able to consult it when a plant didn't fit the Waterfall keys, and to find that there were species new to Oklahoma that we might have in hand. The lists of synonyms and distribution information have been equally helpful. I am so grateful that John and Connie Taylor undertook this tedious task to help expedite the identification of the Oklahoma plants."

Gloria Caddell, Professor of Biology, CSU

Herbarium, University of Central Oklahoma

"I met Dr. Taylor rather late in his life, as he had already retired at the time, but remember very well a field trip he co-led with Connie for the ONPS, along the Talimena Trail in, I think, 1998. It had been very dry, and there weren't many plants in bloom, but the two of them knew every plant we passed, whether blooming or not. Along the way he pulled up a Carex seedling and gave it to me to grow, saying, "This is quite rare in Oklahoma”. It was, and still is. It later bloomed for me on a place I built for it in Cleveland County, and by that time I knew enough to know it as Carex atlantica. But John's most endearing contribution to Oklahoma plants was that '...Annotated List...' At a time when the USDA database was only an unreliable hatchling, apt to go off-line at irregular intervals, that list was the best reference we had for the organization of the Flora of Oklahoma Project. Using it, we were able to determine workloads and make assignments. It is still the best available source for information about whether a plant is native or not, where to look for it, or why it has three scientific names! Only someone who understood and sympathized with the plight of beginning botanists in Oklahoma could have produced such a valuable book."

Patricia Folley, Bebb Herbarium, University of Oklahoma.

"I use the Annotated List constantly, both for my own personal gratification in 
my home landscape and for professional landscape planting projects for clients. It is my bedrock concerning the suitability of planting in the different regions of Oklahoma."

Susan Chambers, Owner

Rose Rock Landscaping, Midwest City, Oklahoma

"I did not have the opportunity to know John Taylor very well; however, I greatly appreciate his contributions to the flora of Oklahoma. In particular, the 'An Annotated List of the Ferns, Fern Allies, Gymnosperms and Flowering Plants of Oklahoma' is an invaluable resource. My students and I use the list several times a week. Student workers (usually work-study students who may not be biology majors) manage our small herbarium and without the list they would be lost. John and Connie's list is the first reference that I use to resolve a nomenclature issue."

Monica Macklin, Instructor of Biology, Joe M. Anderson Herbarium, Northeastern State University

“At 7:30 a.m. on Saturday, March 18, 1989, I left home in Noble to drive to Durant for an ONPS field trip. It was cold and blustery, as March usually is. John Taylor was to be our trip leader with Jim Norman's assistance. I had been on only a few such outings and was excited. However, I had reservations about the weather. It was more like a day to stay inside and read. We were to meet at a restaurant on the outskirts of town.

When I arrived John and Jim were there alone. The three of us were the only ones to show up. I felt badly because John had gone to a lot of trouble to set up a display of things we could expect to see that day, in the school's herbarium at East Central State College. Then we proceeded on an extensive driving and walking trip to several locations and John was just as instructive and patient with only one student as he would have been with a dozen or more. Sixteen years later I don't remember many details except that somewhere we saw seaside alder growing in a bar ditch and I realized that my miniature pinecone earrings that had been dipped in gold were actually seaside alder cones. I had never even heard of them before.

In spite of my earlier misgivings and disappointment that we hadn't had more people, it turned out to be one of the best experiences of my life. I will always remember that trip and all the special attention I received as an only student with two excellent teachers."

Ruth Boyd, Charter member of the Central Chapter of ONPS

"John and Connie Taylor's, $A n$ Annotated List of the Ferns, Fern Allies, Gymnosperms and Flowering Plants of Oklahoma" is one of the most valuable publications about Oklahoma plants I own. It is certainly the first one I reach for when I want to know a plant's range, use, and common name. I wish I could have taken field trips with the Taylors. What an adventure that would have been!"

Marilyn Stewart, Owner, Wild Things Nursery, Seminole, Oklahoma

His work has benefitted many more Oklahoma botanists than he knew or could ever have met. That number will surely increase in the coming decades. SS

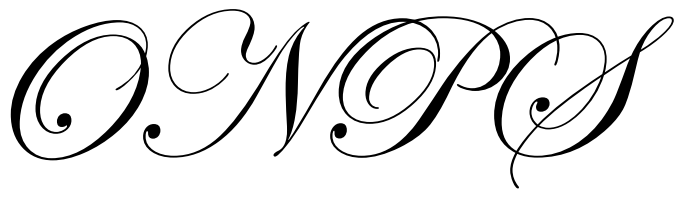

